\title{
The Land Act (1998) and Land Tenure Reform in Uganda
}

\author{
Juma Anthony Okuku*
}

\begin{abstract}
In agrarian societies land is not only the main means for generating a livelihood, it is also a means to accumulate wealth and transfer it between generations. In Uganda, it is a basic source of food, employment, a key agricultural input and a major determinant of a farmer's access to other productive resources. The nature of land tenure, therefore, has profound implications for the development process of nations. As the historical experience of Europe, Asia, Latin America and Africa indicates, land tenure can either impede or facilitate positive socic. econoraic change in a given economy. The Land Act (1998), which aims at reforming land tenure relations in Uganda, is therefore one of the most farreaching legislation enacted by the National Resistance Movement (NRM) government. The new tenure system aims at supporting agricultural development throug!, the functioning of a land market, establishing security of tenure and ensuring sustainable utilisation of land in order to bring about development. This paper discusses three major issues. First, the extent to which the new Land Act (1998) ensures security of tenure to the peasant majority in the country. Second, the issue of its capacity to resolve the long-run contestation between the mailo landowners and tenants (bibanja) holders. And third, the ambiguitie.s and difficulties facing the Act in the process of its implementation must be confronted. The article is based on the textual analysis of the various land laws in Uganda historically. The literature brings out several constraints and ambiguities regarding the land reform process in Uganda.
\end{abstract}

* J:m? Anthony Okuku is a Lecturer in Political Economy, Department of Political Scince, Makerere University, Kampala and a PhD candidate at The Graduate School of Public and Development Management, University of The Witwatersrand, Johannesburg, South Africa. E-mail: jumaoku@yahoo.co.uk and oluku.aj@mgmt.wits.ac.za. J thank the anonymous referees for helpful suggeslions. The usual disclaime: applies. 


\section{Résumé}

Dans les sociétés agraires, la terre ne représente pas uniquement le principal moyen de génération de revenus, mais également un outil d'accumulation et de transfert de richesses entre les différ-ntes générations. En Ouganda, elle constitue une source majeure de ressources alimentaires, d'emploi ; elle représente un important outil agricole ainsi qu'un important déterminant de l'accès des paysans aux autres ressources productives. La nature de la terre a de ce fait d'énormes implications sur le processus de développement des nations. Comme le démontre l'expérience historique de l'Europe, de l'Asie, de l'Amérique Latine et de l'A frique, le régime foncier peut soit freiner soit faciliter un changement socioéconomique dans une société donnée. La Land Act (1998) - Joi relative au régime foncier dont l'objectif est de réformer le système foncier en Ouganda, constitue donc une des législations les plus complètes promulguées par le Gouvernement du Mouvement de Résistance Nationale (NRM). Ce nouveau système vise à apporter un certain soutien au développement agricole à travers l'instauration d'un marché foncier, qui assurerait ainsi une certaine sécurité foncière ainsi qu'une utilisation viable de la terre, afin de faciliter le processus de développement. Cet article aborde trois points majeurs. Tout d'abord il explique dans quelle mesure la nouvelle Land Act (1998) peut garantir la sécurité foncière à une majorité de paysans de ce pays. Il aborde également la question de la capacité de cette loi à résoudre le long conflit entre les propriétaires terriens mailo et les fermiers à bail bibanja. Troisièmement, cet article affirme que les ambiguïtés et les difficultés auxquelles celte loi est confrontée doivent être prises en compte. Cet article est basé sur une analyse textuelle des différentes législations foncières de l'histoire de l'Ouganda. La littérature exploitée révèle un certain nombre de contraintes et d'ambiguités concernant le processus de réforme foncière de ce pays.

\section{Introduction}

There is a broad agreement among economic historians that the 'agricultural revolutions' coincided or even preceded the industrial revolution in European countries. The transfer of land to individual owners as a result of the enclosure movement in England led to the mechanisation of agriculture, resulting in increased production. Virtually all successful land reforms in the 20 th century involved transfer or consolidation of land to tenants and peasants who thus became owner-cultivators (Skarstein 1990:2-5). Through a distributive land reform in East Asia the process was applied with striking success in areas of extreme land hunger as in Japan, Taiwan and South Korea, their specific historical contexts notwithstanding. Small farms in these countries proved that they are unbeatable in ensuring self-sufficiency combined with food for all. This was complemented by a massive transfer of resources for rural development. It is usually argued that such reforms are 
favourable to efficiency and employment as well as equity. In the short-rin, the size of the marketed surplus would also be favoured.

Through the land reform of 1946 , for instance, Japanese farmers received a new incentive to intensify their productive efforts when they became owners of the land. Farmers received a new motivation to make better use of science and technology through improved education, agricultural research, and extension combined with re-organisation of co-operatives. In both South Korea and Taiwan, absentee land ownership was abolished and the land was placed in the hands of cultivators.

Uganda's economy being predominantly agricultural-based with over 80 percent of its people deriving their livelihood directly from land, tenure security that provides for legalised exploitation of this resource is a critical need. This is because secure property rights have a positive impact on increased agricultural production and implications for food security. In terms of the land question, several processes related to the economic crisis and Structural Adjustment Programmes (SAPs) have led to changes in demand, use and value of land in the country. The nature of access, the rights to land, including the right to sell, have changed and become complex. This has been facilitated, partially, by the deepening poverly occasioned by some of the SAPs. An act to reform land is therefore timely. One of the major milestones to reform land tenure in Uganda has been the 1998 Land Act.

The Land Act of 1998, which provides for a land tenure reform, has farreaching implications for agricultural development. It aims at supporting agricultural development through the functioning of a land market, establishing security of tenure, and ensuring the sustainable utilisation of land to bring about development. Sustainability of land reform calls for the creation of conditions for efficient use and development of land markets meeting the requirement of society and individual citizens. This entails the development of administration of the cadastre, land appraisal for taxation purposes, control over use of land, land use planning and monitoring functions.

The land question is immersed in the political economy of Uganda. The exercise of power and power relations impinges on the operations of land markets, on security in land rights, and on security in land tenure. There are a number of problems associated with exercise of power in Uganda today. First, of particular concern, is the prevalence of patronage politics in Uganda where every development programme is viewed in terms of expanding the regime's political base. Hence, a programme of tenure reform is viewed as an opportunity more for the expansion of the political base of the regime than for ensuring tenure security. Public land is likely to be used as a patronage resource for the state to acquire more power. Second, the land reform 
process is hardly linked to other programmes such as the Plan for Modernisation of Agriculture (PMA), which is part of Uganda's broader strategy to eradicate poverty under the guidelines of the Poverty Eradication Action Plan (PEAP) adopted by Government in 1997.' Third, is the problem of sustainability of the reform process and institutions.

This paper critically examines the efficacy of the Land Act of 1998, aimed at bringing about land tenure reform in the context of Uganda's political economy. The paper is divided into five parts. Part one is the introduction. Part two briefly outlines the conceptual framework. Part three locates the study in historical perspective. Part four is the central part of the paper, which examines both theoretically and empirically, the provisions of the Act on the land holding system, control of land use and land management. This is done together with an analysis of chapter 15 of the Uganda Constitution (1995) that deals with land and environment. All these are analysed within the context of the mission of the Act to create a land market, establish security of tenure, and ensure the sustainable utilisation of land resources. Part five is an assessment of the prospects of the Act in bringing about development in Uganda within the institutional and political context of the Land Act debate and the ambiguities embedded in the Act.

\section{Conceptual framework}

The current dominant approach to analysis of land tenure relations is neoliberalism. This approach has been adopted by advocates of the market approach to land reform called 'negotiated' or 'market-assisted' land reform. Debates on land tenure security have been focused on what forms of tenure institutions could provide more security, individualised tenure or indigenous tenure, and in what forms land can be managed, by the state, local community or individuals (Bromley and Cornea 1989). What has been little discussed, however, are the contents of security and social character which security of land rights carry. Izumi (1998b:12-13), attempts a clarification of the issues by segregating the contents of security and the social character of security of land rights as opposed to security in land tenure.

According to this view, security in land rights is attached to certain individuals or groups. Security in land rights is often relational with respect to contradicting relations over land between different social groups: villagers and outsiders, peasants and the state, pastoralists and private investors, where unequal access to land between the two exists. In many cases, a loss of access to land of the former is often a condition for the latter to accumulate land.

Security in land tenure, on the other hand, implies stability in the institutions of land tenure, whicl: contains rules, norms and enforcement mechanisms of the rules. Legitimacy and stability in tenure institutions is necessary 
if individuals are to believe that existing institutions protect his/her rights in land. It is not the legislation of rules but their institutionalisation that provides a source of security in land rights. However, security in land tenure does not imply that everybody has secure land rights protected by the institution. This is because institutions are not neutral, but often reflect power relations in a given society.

Tenure security and secuity of land rights must be seen in a given social and institutional context. It is not that just that secure property rights in land have a positive impact on increased agricultural productivity as they provide incentives to invest. This depends on whose interests these institutions serve. Brenner (1982), drawing on the experience of European development, argues that institutions create vested interests that make change problematic, even in the presence of major technological advances.

The major concern with the current donor-driven conceptualisation regarding the lack of agricultural development in Africa is the absence of a land market. In the literature on African tenure, the land market is discussed as synonymous with land sales and the absence of a land market is blamed as a cause of the inefficient allocation of land (Izumi 1998a:33). The Land Act of 1998 is informed by this conception. This view regarding land markets raises t:vo questions. First, whether existing land sales in Africa, which are considered 'informal land markets', constitute a land market. Second, whether formalisation of the 'informal land market' will ensure a more just allocation and distribution of land.

To conceptualise the lard market adequately, one needs to distinguish between isolated, personalised, non-market exchange and impersonal market exchange. A market itself is an institution which depends on other institutions such as customary, legal, political and other social arrangements, which control market systems, and in the absence of such institutions, a market economy does not automatically emerge (Hodgson 1988).

Therefore, the current neoliberal individualisation of tenure and the notion of land markets are not adequate in societies in the process of transition such as those of Africa. There are both market and non-market forces that inlluence the process. The non-market institutions, particularly the state, are indispensable for the establishment of and the proper working of the market. The stote is largely left out of the neoliberal construction of land markets. The institutionalisation of the land market requires the state to be highly efficient in its intervention in regulating and facilitating the development of the land market, and in administration, including property rights legislation, registration and collection of land tax (Izumi 1998a:34).

The debate on the relationship between land tenure and development continues. What is agreed, how:ever, is that there is a need for land reform for 
sustainable agricultural development to take place. The central element in the relationship between land tenure and development is the concrete definition of property rights, which are crucial for investment in, and development of, agriculture. Land reform, therefore, connotes reform of basic relations among tillers of the land and of basic relations between them and the direct beneliciaries from the land-tiller interaction (Lipton 1991:270).

Poicy-makers seeking to avoid land reform may find it politically convenient to insert provisions that make land reform impossibly difficult; for example, by adding extraneous requirements regarding land confiscation. The fear of land reform should not at the same time allow for an over-liberal definition that may allow some pseudo-reforms to acquire kudos for real reform. Land reform may fail to achieve its stated goals because it does not attack the rural power structure, which may be rooted in the unequal distribution of owned land.

Second, land markets may not necessarily be activated as a result of registration or titling. The mere lact that land sales take place does not mean that they promote economic efficiency by transferring land into the hands of dynamic cultivators. Land markets, as is the case with other types of markets, are social organisms interacting with and perverted by the state and society at large, and are political entities permeated by power relations of a diverse kind (White 1993). Successful negotiation and contestation in the markct depends on access to power. It is therefore necessary to understand what is power, what makes power, how power is acquired, and how to exercise power in agrarian societies. Any reform of the land tenure system must take into consideration both the market and non-market configurations (lzumi 1998a:50).

Third, reform of land tenure must go beyond titling and distribution of land. There must be an agrarian reform - that is, reform of production and social relations. I must involve the provision of technology, the extension of farm management education and research, the provision of credit and the reorganisation of co-operatives, to enable farmers to participate effectively in the increasingly hostile market based on individualised entry advocated by the neoliberals.

Finally, there is a theoretical case for a land ceiling and a land tax. An eflective distributive land reform must include a land ceiling beyond which an individual may not own land. It is an essential point in ensuring a more ecpual ownership of land leading to a fair income distribution. Land taxation, with progressively higher rates as land value and size of ownership holding incre'se, will, it has been argued, provide large landowners with the incentive 10 sell parts of their land in order to escape the higher tax rates, (Mijumbi 2000:i0). A part from renting out and selling parts of land, it may encourage 
landowners to invest in the land 10 produce mor $\%$ as to raise the funds for payment of tax. When well managed, tax resoures may become a source of funds to lend to larmers to make improvements in the land and for the development of rural infrastructure. Most of these theoretical issues are largely passed over in the Land Act 1998.

The land question in Uganda encompasses profound historical and political issues that go beyond the framework of neoliberal theory. Both forms, the market and non-market land transactions, co-exist. The minimal state intervention suggested by neoliberal theory is unlikely to ensure the emergence of a land market and its efficient functioning. A review of the history of land legislation in Ugancia indicates that socio-political issues have not been given sufficient consideration in the enactment of laws. Economic issues, although important, are not sufficient on their own.

\section{Land legislation in Uganda: Historical perspectives}

To understand the current efforts to reform land tenure in Uganda, one must look at the historical context. Most of the intricacies involving the land tenure reform were created by past land policies, both colonial and postcolonial. The effectiveness or failure of land legislation can only be assessed within its past political, economic and social context. This is because the underlying mission of past legislation, as for the Act today, was the creation of markets, the establishment of security of tenure and to ensure the sustainable utilisation of land (Mamdani 1976; Mukubwa-Tumwine 1977; Bazaara et al. 1992; Trout 1994).

The colonial govemment chose to introduce individual rights in land in the form of freehold tenure starting in Buganda. The colonial state intervention produced conditions and legal mechanisms for the emergence of land markets. Sir Harry Johnstons, the author of the 1900 Agreement between the British and Baganda, believed that he was simply formalising and preserving traditional rights and privileges in land, but the rights under the agreement represented a fundamental shift from the traditional system (Mukwaya 1953 and West 1972). Under the terms of the 1900 Agreement, of the total of 19,700 square miles of the land of Buganda, more than 8000 square miles, the mailo, were allocated to the king and private individuals mainly chiets, notables, the church and the colonial state (crown land). Outside Buganda, the colonial state assumed control over unappropriated land by declaring it crown lands.

The outcome of the two approaches to land legislation was twofold. In Buganda, the colonial policy consolidated the political and economic power of the chiefs and mailo landowners while at the same time rendering the Bakopi (the peasants/the poor), and tenants dependent on the landlords. Out- 
side Buganda, a new elite, particularly collaborators, with colonial backing acquired land and power that they had never possessed before. The general population in the meantime lost access to the so-called 'unappropriated lands' (Bazaara, et al 1992:8). At the same time, as a punishment to Bunyoro Kingdom for having resisted colonialism, the colonial state settled the Baganda, mostly as absentee landlords, in Kibaale, which came to be known as the 'lost counties'. These arrangements had serious political implications in the post-independence period.

Our major concern here, however, is with the implications of this legislation for land ownership and transfer. First, land became a saleable commodity at the complete disposal of individuals, who had legal obligation neither to the Kabaka nor to the people settled on their land. Second, within a few years land became an important commodity for investment and the generation of continuous wealth through the exploitation of hired labour with the rise of employers and employees among the indigenous population. Third, and perhaps most far-reaching, the 1900 Agreement excluded the rest of the population from enjoying similar rights in land as the chiefs and other mailo owners. Not only were they deprived of the rights of ownership ab initio but also their right of occupancy (Mafeje 1973:6-7). Politically, this set the stage for the Bataaka movemen ${ }^{4}$ in the 1920s, which was due to the dissatisfaction with the 1900 Agreement.

The mailo estates, however, did not remain intact, but were broken up over time, as the land market emerged. The original large mailo estates were split into smaller lots, and the number of owners increased. Inheritance and gifts were responsible for this trend, but the land market played a role. Mukwaya (1953:34) described sale as a primary factor responsible for the increase in the number of landowners. In his sample from two central region Sub-counties, 57.8 percent of landowners had purchased their land. As a result of divisions through inheritance, gift, and sale, there may have been as many as 200,000 owners of mailo land by 1974 (Trout 1994:20).

There were three pieces of legislation in the colonial period. First, in 1903, the Crown Lands Ordinance as a forerunner of public land policies was enacted to provide for the manner in which Crown Land holding emerged. This included freehold and leasehold. Second, in 1908 a Land Law was passed by the Buganda parliament, Lukiiko, defining the system of tenure introduced by the 1900 Agreement. It also saw the implementation of rent requirements by tenants and peasants, busulu and envijjo. The tenants and peasants had to pay dues every year, busulu and a tithe, envujjo in respect of each acre. The 1920s saw agitation by the Bataaka who were dissatisfied with the Agreement, which had not specified the precise rights peasants had. At the same time, there were increased demands by landlords for cash and 
commodity rents as peasants expanded the cultivation of cash crops. The implication of this extortion was that it acted as a fetter on production as high rents, envujjo and busulu were imposed on the tenants and peasants.

Third, the colonial state responded by enacting the 1928 envujio and busulu laws that put a limit to the amount of rent that a landlord could levy while guaranteeing the tenant complete and hereditary security of tenure so long as he continued the effective cultivation of his land. The state through these laws achieved three goals. First, the material basis of power of the landlords and chiefs was severely limited. Second, it gave the peasants security of tenure provided they cultivated cash crops for export. As a result, the tenant found himself in a more secure position than before 1928 (Mamdani 1976:124). In law, the security of the mukopi (peasant/tenant/poor), was protected against arbitrary eviction. The chief could no longer plunder the peasant's possessions and a law, which fixed the landlord's share of economic crops at a much smaller amount than which he had previously demanded, defined his obligations. However, as Mukubwa (1977:59), observes, 'it should not be forgotten that the exploitation of the peasant was not ended, it was only checked or mitigated'. The third goal achieved by the colonial state was that the protection from eviction led to an increase in the production of cash crops in demand by British industries in the 1930s.

No major land legislation was enacted until the 1950s. In a report to the colonial Secretary of State for Colonies in 1951 by then Governor of Kenya, Phillip Mitchell, it was argued that small-scale cultivation of land under tribal conditions of tenure and according to African methods could do more than sustain subsistence. The East African Royal Commission (EARC), was set up. The Commission made three major recommendations, namely, there should be, first, a progressive encouragement of individualisation of the title in the African hands. Second, there should be a corresponding reduction of communal and other restrictive controls over African lands. Third, a land policy that would ensure mobility in the transfer of land in order to enable access to land for economic use was recommended. According to Kiapi, (1975), the government proposals based on the Commission's recommendations were rejected in some districts. In Teso and Lango riots ensued.The Commission's recommendations remained largely unimplemented.

In the 1960s and 1970s, there were several pieces of land legislations. Here I consider those that were pertinent to the issue of security of tenure and land acquisition. Following the recommendations of the 1961 Constitutional Conference, Lancaster House, London, the Public Land Act of 1962 was enacted. This was an attempt to establish a clear land policy before independence. The Act converted all former Crown land into public lands, subject to customary tenure, without specifying the limit to which a person could 
acquire this land. The Land Acquisition Act of 1965 provided that the Minister, whenever he was satisfied that the land was needed for public purposes, could by statutory instruments make a declaration to that effect. Non-Africans were not allowed to occupy or enter into possession of land or make any contract to purchase or lease any land without the consent of the Minister, by the Land Transter Act of 1965.

The question which none of these Acts raised was; who was going to be the subject of rural transformation in Uganda? A partial answer was given during the 1966 crisis when the oligarchic superstructure of Buganda was forcibly dismantled by the the government of Milton Obote, Uganda's first postcolonial Prime Minister. The government, however, had no clear plan for land reform. The most it did in Buganda was to abolish official mailo land, which by then amounted to no more than 4 percent of the land, and the transfer of all public land to the national government (Mafeje 1973:22). Put in a political context, the first Obote regime was unable to deal effectively with the oligarchy due to its lack of political organisation at the grassroots level. The regime was, as a result. confined to administrative manoeuvres and was extremely fearful of rebellion in Buganda in the event of the government seriously tackling the sensitive land question.

The other two important land laws in the post-independence period were the 1969 Public Land Act and the 1975 Land Reform Decree. In 1969, all public land was brought under the Uganda Land Commission. It was made. lawful for persons holding land by customary tenure to occupy without grant, lease or license from the controlling authority of any public land vested in the Commission. Sub-section 24 of the 1969 Public Land Act required the consent of customary tenants before such land could be surrendered for any other purposes. This was a vital protection for the majority who held land under this tenure.

The 1975 Land Reform Decree reversed whatever security the peasants had acquired by the 1969 Public Lands Act by declaring all land in Ugandat to be public. The Decree had a number of declared aims. First, it aimed to end and prevent 'unreasonable' areas of land being left undeveloped by their owners or occupiers, especially individuals without justification for doing so. Second, the decree aimed at distributing land use to as many people as possible, especially where there was great demand by those who needed land for 'development' projects. Third, the decree sought to provide security to land occupiers or users but to subject them to the general interest and needs of the public. The Decree abolished mailo, freehold or any other absolute ownership rights. Absolute titles were converted into leasehold under the Uganda Land Commission - 99 years for individuals, and 999 years for public bodies, religious and other claritable organisations. The busulu and 
envujjo tenants were turned into customary holders without the condition of rent payment. They were, however, prohibited from transferring any title in land otlier than the improvements and developments on the land and provided for eviction after a three months notice. It abolished the power of customary tenants to stand in the way of development by refusing grants to lease to those most able to develop the land (Bazaara, et al 1992:15).

What were the implicaticins of the 1975 Decree? The first major implicaltion is that the Decree opened the floodgates for speculators and land grabbers. State burealucrats and state agents, particularly army officers, used state power to grab land. This was because in the inflationary economy of the 1970s, the durabili, and ability of land to maintain real value made it a desirable asset for preserving wealth (Juma 2000:18). Second, although the decree abolished rents, it did not diminish the power of the land-owning class, which could, on the pretext of 'developing' the land, dispossess the tenants (Bazaara 2000:6). Third, there ivas m security of tenure as land could be expropriated from the peasants in the nmme of 'development' projects or the 'public' interest. In general, however, the decree had a limited impact as the average citizen remained unaware of it an tomained largely unimplemented.

The fundamental issues emerging from the various land enactments are those of security of tenure and the definition of property rights, which determine the range of possible transactions concerning land. They generally failed to define the central subject of rural transformation. This is where the Land Act 1998, appears to be so different. But due to some ambiguities embedded in it, it may not be able to resolve some of the contentious issues surrounding the land question in Uganda.

\section{Land Reform and Policy in Uganda}

By the late 1980s, there was no systematic land policy in Uganda. The initial formulation of such policy was in 1983. According to the former Permanent Secretary, Ministry of Planning and Economic Development, Tumusime-Mutebile, the history of the Land Bills dates back to this year. He states:

Recognizing the importance of agricultural policy in the rehabilitation and development of agricultural sector, and in agreement with the World Banik under IDA - Agricultural Rehabilitation Project, government esans in 1983, an Agricultural Policy Committee supported by the

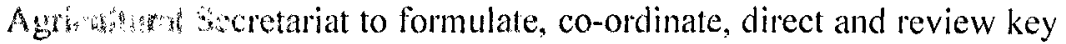

policis and trogrammes in the agricultural sector (Bazaara 2000:9).

The calls for the market-based land reforms followed from a renewed focus by donors and government to enact enabling policies for agricultural devel- 
opment. Land in this case had to be transformed into a tradable commodity. The government of the day could not formulate a land policy due to the civil war of 1981-86. This was left to the NRM regime, which captured power in 1986. The NRM abandoned its Ten Point programme, a policy aimed at building an 'independent, integrated and self-sustaining economy', and embraced neoliberal policies in 1987. The policy of market-based land reform had therefore come full circle.

This embrace by government of market-based land reform was reinforced theore ically by the Makerere Institute of Social Research (MISR)-Wisconsin Land Tenure Centre Study, "The Land Tenure and Agricultural Development in Uganda', with its obsession with creating land markets. (MISRWinscosin Study 1989). The major problem with this Study is that it was based on interviews of a suall sample of farmers in Masaka and Luwero districts, all located in South-Central Uganda, yet it came out with recommendations for a uniform tenure system for the whole country. Therefore, the specific problems in different parts of the country were not taken into account (Ddungu 1991). A study with such a narrow focus should not have been a basis for the national institutional framework of land policy. While this shortcoming has been taken care of by the various studies for the implementation of the Land Act in the various districts, the starting point should have been the national dimensions of the land question.

Finally, politically the land question, especially in Buganda, came to be subject to the power games of the NRM regime. Political interests of the NRM acted as shackles on the process of enacting a law that would facilitate the carrying out of a thorough land reform. In the run-up to the constituency Assen:bly (CA) elections in 1994, there was a politically motivated, hurried restoration of traditional rulers' properties, including land and regalia, particularly that of Buganda in 1993. This precluded any major tenure reforms in Buganda, the centre of landlord - tenant relations.

The resulting Land Ac: of 1998, therefore, is theoretically informed by the modernisation paradigm with an IMF/World Bank inspiration, and politically by the power plays of the NRM regime. It encourages and supports investment through making land, in both rural and urban areas, more readily available to the market. It is within this context that the idea of a new land policy was conceived.

The central aim of the Land Act, however, is to reform land tenure relations in Uganda. The fundamental question is, are the prospects of the Land Act 1998, of bringing about agricultural transformation, qualitatively different from earlier initiatives? Uganda has four major tenure types that the legislation aims to reform. The Act recognises these four land tenure forms:Customary (communal), mailo, freehold and leasehold. Thus: 
Section 3(1) of the Act and article 237(1) of the 1995 Constitution state that, 'All land in Uganda shall vest in the citizens of Uganda and shall be owned in accordance with the following land tenure systems: a) customary, b) freehold, c) mailo and d) leasehold'. Section 3 (2) states that, 'The freehold and mailo tenures and estates which were abolished under the 1975 Land Reform Decree, are hereby restored'.

These provisions have different implications for the development process. There are a number of underlying assumptions by those who relate these systems of land tenure to development in general and Uganda in particular.

\section{Customary tenure}

First, under communal or customary tenure, a community or group bases the fundamental principle of land ownership on collective ownership. They enjoy usufuctory right in land and it is transferred through inheritance. Both the Constitution and the Land Act recognise customary tenure and aim at defining ownership rights:

'... All Ugandan citizens owning land under customary tenure may acquire certificates of ownership' (Article 237(4)(a) and Section 4(1) of the Ac., 'Any person or community holding land under customary tenure may acquire a certificate of customary ownership...' Section 5 (1), reads: 'Any person or community holding land under customary tenure may convert the customary tenure into freehold'.

The ultimate aim is to transform customary tenure into individually-owned estates, held increasingly in the European-derived regimes of land markets and private tenure, freehold or leasehold. The underlying assumption of the Land Act is in line with an earlier argument in 1981 by Makubuya that customary tenure is one of the basic hindrances to socio-economic development in Uganda (Makubuya 1981).

There are a number of market-based arguments advanced against customary tenure that ignore its socio-political underpinnings. First, there is the view that there is insecurity of tenure because land is collectively owned and it is difficult to use it as collateral. Second, is the argument that where land is collectively owned, there is a tendency to misuse the land resources via irrational husbandry techniques such as shifting cultivation/grazing, which are an inefficient, and uneconomic way of land use. Third, the inheritance practices lead to fragmentation and therefore, the rise of uneconomic pieces of land (Bazaara 1992:4). Hence, for development to take place, in this view, customary tenure must be aholished.

While these criticisms may have some validity, over time there has been an evolution of tenure in Uganda such that to continue referring to existing system of land tenure in some parts of the country as 'customary' is not 
accurate. First, customary land tenure is ever being contested and reconstructed. The nature of access, the right to land including rights to sale in present-day Uganda, are a far cry from this static notion of customary tenure. It has been undergoing individualisation and change. As Deininger and Feder (1998.5) state in a general observation:

... Contrary to the widespread misconceptions, communal tenure systems are generally not based on collective production. Instead production on arable plots is normally undertaken by individuals who are residual claimants to output implying that, on arable plots, incentives for effort supply by individual cultivators are likely to be appropriate.

At a more empirical level, the Land Act does not resolve the complications involved in common property. Under custonary tenure it is difficult to delineate communal areas such as clan land and hunting grounds. Neither does it put in place the means of protection of individual interests from communal rights. The provision for acquiring a certificate of customary ownership further creates ambiguities. It is difficult to ascertain the status of a certificate of customary ownership, particularly its value compared to other certificates of title. There also arises a problem of differentiating these certificates from title deeds. As a result, it becomes difficult to ascertain rights. The need to ascertain rights is important because a certificate of ownership is a first step to the acquisition of title deeds, which can be used as collateral for loans.

Finally, some problems arise regarding the conversion of customary tenure into freehold. While conversion of customary tenure to freehold as enshrined in the Act might provide more security of tenure, those who occupy land under customary tenure are mostly illiterate. The conversion procedure is bound to be complicated and confusing, as public education around the Land $f$ ct has largely been ineffective. Second, due to the high level of poverty in the countryside, peasants may not be able to meet the cost of a survey. The threat of fragmentation under customary tenure noted above brings out another reality: the rising inequality and land concentration in some parts of the country. In development terms, therefore, there must be an institutional framework for addressing these concerns as some elements of customary land ownership transcend economic reasoning and prescriptions. These considerations are largely lacking in the Act.

\section{Mailo tenure}

The Land Act 1998, restores the mailo tenure, which had been abolished by the 1975 Land Reform Decree. Mailo tenure is prevalent in Buganda and some parts of other kingdoms. Mailo tenure was comprised of land allotments to the Kabaka and his chiefs following the 1900 Agreement, and they 
were measured in square miles: hence the coinage by the Baganda, mailo. The immediate implication of mailo tenure is that it excludes the rest of the population from enjoying similar rights in land as those of the Kabaka and his chiefs. The population is not only deprived of the rights of ownership but also the rights of occupancy. The rest of the population, therefore, does not possess security of tenure and property rights in addition to payment of busulu and envijjo. In addition, ownership of land remains an exclusive right of the privileged by birth or because of financial endowment (Mafeje 1973:7-11). Clearly, the restoration of mailo puts a brake on the process of making the land available for investment as a stimulant to economic growtl. Secure individua! rights are crucial for such investment. For political reasons, as we shall see, the land question in Buganda could not be resolved under the Act in the interest of the majority: peasants and tenants.

The restoration of mailo tenure by the Land Act raises two major problems with regard to bona fide occupancy and registrable interest. First, a bona fide occupant is a person who has a landlord's permission to utilise the latter's land or has occupied public land for a period of time exceeding 12 years. The Act provides tenure for a bona fide occupant who is issued with a certificate of occupancy. As Section 9 (1) of the Act states: 'A lawful bona fide occupant on registered land shall enjoy security of tenure on the land'. The registered owner is entitled to a nominal annual ground rent of Sh. 1000/ (\$0.5). Such low rent levels may not encourage owners to let land. According to section 9 (5), of the Act, 'If a statutory tenant fails to pay the prescribed ground rent for a period exceeding three years, the registered owner shall give... notice of his or her intention to terminate the tenancy'.

The clause is ambiguous, and a sense of insecurity still prevails as regards tire tenant, as he/she does not possess concrete property rights over the land he occupies, a major precondition for investments in land. Nowhere is the question raised more dramatically than in Kibaale (Mijumbi 2000:12-13 and Bazaara 2000:6). The 1965 referendum, which was supposed to resolve the question of the so-called 'lost counties' of Buyaga and Bugangaizi, did not addi ess the issue of land ownership. Despite the administrative return of these counties to Bunyoro Kingdom, the mailo land system remained intact with Baganda absentee owners retaining their mailo certificates.

The Kibaale question surfaced during the debate leading up to the Land Act. It was recognised that the best way out of this dilemma was to compensate the Baganda absentee mailo landholders and allow the Banyoro tenants to take full possession of the land. It is the Kibaale question that gave initial consideration to a land fund with the expectation that the required compensation to the Baganda mailo landholders would come from it. During the debates, it was argued that the Kibaale question could not be dealt with in 
isolation but similar situations such as that in Nyabushozi, President Museveni's home county, would also merit the same attention. Patronage politics and et/unic mindsets are likely to interfere with the operation of a land fund. Kibaale residents have expressed concern that their case has lost priority to Nyabushozi, although they were the main cause for the establishment of the fund! The Land Act, with it is provision of a Land Fund is an improvement, but may not resolve the question adequately.

The second problem with the restoration of mailo tenure is the issue of registrable interest. Registrable interest is intended to facilitate interaction between tenants and landlords. It ensures that the landlords do not evict tenants as they please. This remains ambiguous. To have registrable interest necessitates a certificate of ownership. It is contradictory to issue a tenant a certificate of ownership when an absentee or available landlord has a land title. This creates overlapping claims for the land with negative consequences for the definition of property rights and creates unnecessary encumbrances. To compound the problems, the large original mailo estates were broken up and the number of owners has, through inheritance, gift and sale, greatly increased. This changed reality calls for a transformation of the tenure relations, not the restoration of mailo tenure as the Act wartants.

\section{Freehold and leasehold}

Freehold and leasehold are the other systems of tenure recognised by the Land Act. Freehold and leasehold fall under what is broadly referred to as individual tenure. Individualisation of land is a process whereby 'a person or a group or family is able to register or record freehold title to the land held customarily by the person or the group' (Obol-Ochola 1970). This implies, 'a reduction of community controls over land use and distribution, enhancing the rights of the individual landholder/farmer' (Bruce 1986). Leasehold tenure is prevalent on publ $\vdots$ land. Both freehold and leasehold tenure have a limited spread in the country. The current market-driven reforms aim at making freehold and leasehold the predominant forms of land ownership, the ambiguity around both customary and mailo tenure notwithstanding. Due to the current excitement among foreign investors, the acquisition of leasehold in land became an issue, which was addressed by the Land Act. Section $14(1)$, provides that: 'A non-citizen may acquire a lease in land...', and subsection (3) adds, 'A non-citizen shall not be granted a lease exceeding ninety nine year's'.

While a 99 year lease should be reasonable for any serious investor, the demand by some of the investors that they acquire 999-year leases or freehold ownership has serious implications for citizens. Ownership in perpetuity by non-citizens, would, first, deny the citizens the opportunity to earn 
ground rent from wealthy investors, which they could use to expand investments on land or in other sectors of the economy. Second, the ability of noncitizens to alienate land from citizens poses the problem of citizens becoming landless. Without a parallel rapid industrialisation process to provide jobs, this can only spell social disaster in both rural and urban areas.

The current market-driven reforms, as embedded in the Land Act, are based on a number of assumptions as far as land tenure and development are concerned. Optimism about these reforms may be a result of theoretical carelessness in the face of empirical reality. First, it is argued that individualisation of land tenure (leasehold and freehold ownership) increases tenure security of the landholder, thereby reducing the economic costs of litigation over land disputes (Barrows and Roth 1990:268). This, as a result, provides incentives for agricultural investment, gives farmers access to credit, reduces fragmentation of land holdings, and reduces conflict over land, hence freeing up resources which would have been used for litigation (Platteau 1995:15). Thus, it is also presumed that individualisation of tenure increases investment by improving tenure security and reducing transaction costs. This increases the likelihood that the producer will capture the returns from investment. Second, it is assumed that individualisation will cause a land market to emerge. Therefore, according to this view, land will be transferred to those who are able to extract a higher value of product from the land as more productive users bid land away from less productive users (Barrows and Roth 1990:26).

These assumptions raise a number of issues that make the correlation between title and long-term investment problematic. First, the use of credit for agricultural purposes may not increase following land titling simply because there may be no attractive investment opportunities in agriculture or because some enabling conditions are missing. This typically occurs when no technological package suitable for intensive agriculture is on offer. Second, in a situation where the required infrastructure, input-delivery, output marketing or extension services are not available, the market-based expectations of tenure individualisation to bring about development may not be realised (Piatteau 1995:28).

Moreover, the critical importance of other-than-tenure constraints makes it difficult to establish the relationship between freehold titling and the use of mortgages. The existence of legally registered titles, even in conditions where land is easily appropriable, is not a sufficient condition for the increased use of credit for agricultural investment as Okotli-Ogendo (1982), observed in the case of Kenya: '...Farmers who received land titles did not expand credit use because of constraints on the supply of credit. In some 
areas, credit volume was not increased but simply redistributed to larger farms owned by more wealthy individuals'.

More importantly, land markets may not necessarily be activated as a result of registration/titling. The mere fact that land sales take place does not mean that they promote economic efficiency by transferring land into the hands of dynamic cultivators. Evidence from the Kenya land reform process indicates that 'Those purchasing land did so for the sake of speculation, future security for their sons and cash borrowing power... Over half of those held against titles in cotton growing areas had been taken out by land purchasers, but not all for agricultural purposes' (Barrows and Roth 1990:277).

The Land Act does not spell out a ceiling on land ownership beyond that it would be taxable. Therefore, the land policy does not seek to promote an equitable distribution and access to land by all citizens. This opens room for speculation in and hoarding of land. There is considerable latitude to speculate in Uganda since there are no development conditions linked to occupation (where one would lose the right to that land if left undeveloped for a specified duration) (Mijumbi 2000:16). This is because the land's durability in the context of political instability and its ability to maintain real value in an inflationary environment makes it a desirable asset for storing value. The above reality goes against the neoliberal optimism that land will be transferred to those who are able to extract a higher value product from land as more productive users bid away from the less productive users.

\section{Acquisition of land by government}

The Land Act empowers government to compulsorily acquire land in the public interest. Section 15 (1) states, 'Government or local government may acquire land for public use, public safety, public order, public morality, public health and in interest of defense...', and Sub-section (2) states, '...the government or local government may acquire land in the public interest...'

This clause retains the possibility of the arbitrary acquisition of land by the government, as was the case in the 1975 Land Reform Decree. There is also the issue of the definition of 'public interest'. Who determines the 'public interest'? It is likely that compulsory land acquisition will become more common as the economy becomes more prosperous and land becomes more valuable. To compound the issue, the governments (central and local) are not bounc: to provide alternative land or compensation and need not consult. Lack of consultation and the vague definition of 'public interest' remain major shortcomings in the clause, as they do not guarantee private property in land ownership and land as a human right.

The Land Act also aims at ensuring the sustainable utilisation of land. In this regard Section 17 (1) provides that, "The Government or local govern- 
ment shall hold in trust for the people and protect natural lakes, rivers, wetlands, forest reserves, game reserves, national parks and any land reserved for ecological and touristic purposes for the common good of citizens of Uganda'.

This clause raises two issues. First, it is not clear how much control of natural resources the central government is willing or able to devolve to local governments. There is no guarantee that the government will not encroach on these resources in the 'public interest'. Second, government has an uphill task to ensure environmentally friendly use of land in the context of the exicing poverty and in the absence of a technological package accompanying the land legislation. Nor are the communities that depend on these resources provided with alternatives.

\section{Land management}

The Land Act provides for a decentralised land administration from the Ministry of Lands, Housing and ?hysical Planning, to the District Land Boards. The role of the state has changed in the area of management as the locus of control is shifted to the Uganda Land Commission and below it, District Land Boards and Land Committees. These institutions raise a number of questions. First, under what conditions are these institutions being created and maintained? Whose interests are these institutions likely to serve? These questions are important as power relations determine property rights and political institutions that may facilitate or hinder the technical or production relations changes that are necessary for the emergence of a namic development process.

\section{Uganda Land Commission}

The central interest here is the composition and powers of the Uganda Land Commission as these have a direct bearing on the security of tenure and the property rights in land. First, let us consider its composition. Section 20 (1) of the Act provides that, "The commission shall consist of a Chairperson and not more than four other members appointed by the President with the approval of Parliament'.

The major concern here is the idea of appointment of the members of the Commission by the President. In a patronage-based political economy like Uganda, the Commission is likely to reflect political-ethnic biases with a lack of representativeness and meritocracy as its hallmark. Institutions in such a context create vested interests that make change problematic. Second, the Commission has wide-ranging powers as outlined in Section 26 of the Land Act. The commission may:

'(a) acquire by purchase, exchange or' otherwise hold land rights, leasements or interests therein, 
(b) erect, alter, enlarge, improve or demolish any building or other erection on any land held by it,

(c) sell, lease, or otherwise deal with the land held by it, among others'.

The Land Act does not spell out accountability mechanisms through which members of the Commission will exercise such wide-ranging powers. Given such powers, this is very dangerous for some citizens. The President or individual members of the Commission are likely, in an increasingly personalised and vindictive political atmosphere, to use these provisions to deny security tenure and rights to property of individuals or organisations not in their political favour. It is a historical fact that dominant groups set up institutions that mainly serve their narrow interests.

\section{District Land Boards}

The Land Act in Sections 29-37 provides for the establishment of District Land Boards, and their membership, functions and powers among others. The boards, "...hold and allocate land in the district which is not owned by any person or authority', as well as 'facilitate the registration and transfer of interests in land'.

The powers of the boards raise some issues of concern. Historically, district officials have not been known for their impartiality. As it is in the case of the Uganda Land Commission, this clause does not spell out adequate accountability mechanisms to which members of the District Land Boards can be held answerable. There is the likelihood of corruption and land grabbing in the process of registration and transfer of interests in land - as has been the case during most of Uganda's post-independence history. The district land boards are likely to be filled with political appointees with a disregard for all forms of merit and capability. This can only put a brake on the process of agrarian transformation in the country.

\section{Land committees}

Section 38 (1) of the Lan' Act provides for: '... a parish land committee consisting of a Chairperson and three other members appointed by the District Council on the Recommendations of the local council'. At the same time Article 243 of the Constitution (1995) establishes land tribunals.

While the land committees and tribunals could help in resolving disputes at the lower level, they are bound to suffer from the shortcomings of the district land boards, that is, corruption, political vindictiveness, lack of merit and capability. But most importantly, their formation is likely to expand the land bureaucracy beyond manageable proportions. Third, the Land Act is not clear on what the role of Local Councils (LCs), would be in either the 
administration of justice or in the allocation land. The LCs have increasingly become aligned to the ruling party, the NRM, as they have been integrated with the Movement Council, MCs, which are organs of the ruling party. This raises the fear of political bias in their operations on land matters. It is, therefore, suggested that they should keep out of land issues, as their involvement is likely to impact negatively on those in the rural areas who do not subscribe to the NRM. They are likely to become agents of rural oppression.

\section{Prospects for an effective land reform}

Seven years after its enactment, the provisions of the Land Act have hardly been implemented. However, its provisions are a marked improvement on Uganda's land policy in the past. When implemented, the Act will confront a number of limitations both in the short-run and medium term. First, it has limitations with regard to ensuring security of tenure and a concrete definition of property rights, which determines the range of possible transactions concerning land. Second, the institutions governing tenure and exchange that determine who bears the costs associated with transferring rights, are unlikely to be based on merit and be accountable to the people. Third, the Act is unlikely to have a significant positive impact on the supply of commercial bank farm credit, as most farmers may not possess land titles over the medium term. Fourth, in the short to medium-term the impact of the Act on the rural land markets ir. likely to be dismal. This is because it hardly takes into consideration the critical importance of other-than-tenure constraints embedded within Ugandan society.

At a general level, there remain a number of ambiguities in the land policy as discussed above. These constraints, however, must be understood within the historical and political developments of the country. The terrain on which the Land Act was enacted precluded a more distributive, far-reaching reform.

\section{The institutional and political context of the Land Act debate}

The discussion of the Land Act and land reform in Uganda can best be appreciated when it is located in its political and institutional context. The political process through which the Land Bill and Act were produced is one of the sources of the constraints that the Land Act confronts in bring about land reform.

First, the debate about the land question, both during the Constituency Assembly (CA) and after, was conducted in the context of mutual suspicion regardirig land grabbing. As Mijumbi (2000:4) notes, some mailo landholders regarded the Bill as having a hidden agenda to dispossess the Baganda of their land. To the Acholi and other nationalities from predominantly 'com- 
munal' areas, the Bill was a case of confusing them and taking away their 'communal' land. Because government rushed the Bill through Parliament. it did not undertake extensive sensitisation to allay these fears.

Second, the land question had become politically explosive after the 1996 General Elections. The landowners in Buganda, through whipping up ethnic sentiment, had successfully forged an alliance with Baganda tenants. Third, and most important, by the time of the Land Act 1998, the NRM had changed its position regarding the land problem.

As Bazaara, (2000:16) observes:

After the broad-based political arrangement came to an end, the legitimacy of the NRM in Buganda was based on the alliance between NRM and the landlords. This is why the NRM returned the property (ebyaffe) of the former kings. Resolving the land problem in favour of the tenants would immediately cause antagonism between the NRM and Buganda landlords. The other side to this was that alliance with landlords was crucial in its effort to lock political parties out of Buganda.

Here, the NRM was taking an ethmic and sectarian position as far as Buganda is concemed, to advance its political interests in retaining power, contrary to its professions.

Third, the NRM leaders were no longer the paupers of 1986 when they captured power. By 1998, they had transformed themselves into some of the largest landowners in the country. ${ }^{5}$ As well, over the years, state agents and bureaucrats mainly allied to the regime, have used their proximity to state power to acquire loans, mainly from the former state-owned bank, Uganda Commercial Bank, (UCB), to purchase and acquire leases to large tracts of land, which they are now eligible to transform into freehold. The NRM and landlords' representatives in parliament walked together hand in hand out of common interest against the enactment of a Land Act that would provide for remedial measures for the land that may have been fraudulently acquired in the past. The concerns for equity, justice and social change in land relations in Uganda were sacrificed at the altar of power politics and narrow class interests. Given the institutional and political context of the debate and the enactment of the land law, there was little chance of instituting a radically distributive land reform that took into consideration issues to do with equity and historical justice.

\section{Conclusion}

What conclusions can we draw? The Land Act, though an improvement over the past legislation, largely ignores a number of crucial socio-political and theoretical issues. The Act must move away from the obsession with donordriven conceptualisation, to a more concrete understanding of the Ugandan 
social context. This is because some of the prescriptions laid out by neoliberalism may not be adequate to address the land question in the country. The nature of the land question in general, and land markets in particular, transcends economic reasoning and prescriptions. What was needed was a more rigorous law, which when implemented would make a difference in the lives of the people. A radically distributive land reform where peasants would be given title deeds and not certificates of occupancy was needed. This could have been followed by extension assistance, (management skills, technology, seeds, marketing), to ensure that farmers become more productive. This is because all successful land reforms have had extension assistance as a cornerstone in their implementation. The Land Act deviates from these recent examples of countries that have made tremendous transformation of their economies, their different historical contexts notwithstanding.

What is needed is a radically distributive land reform, but giving proper consideration to the peculiar characteristics of the land question in different parts of the country. What essentially this entails is a radical revision of existing land relations and in particular the abolition of the landlord-tenant relations where they exist, not their restoration, as in the Land Act 1998. To resolve the land question would entail linkage of the political, economic and social variables operating in Uganda's political economy. This calls for political courage and ideological clarity regarding the intentions of land reform measures - not opportunism and power games. In the final analysis, the need for fundamental land reform for agrarian change to occur in Uganda is inescapable. It is like Muhammad Ali's fist: 'you can run away but you cannot hide'.

\section{Notes}

1. The Poverty Eradication Action Plan, (PEAP), which is the framework for the erarication of poverty over the next two decades, and the Plan for Modernisation of Agriculture, (PMA) whose objective is to achieve modernisation through improving land laws and the formulation of a comprehensive land use policy, operate as if they were mutually exclusive and working at cross-purposes.

2. Mailo, the land allocated to the Kabaka and his chiefs by the colonial governors, was measured in terms of square miles, hence the coinage by the Baganda, Mailo. Kibanja (singular) Bibanja (plural) refer to plots held by tenants on mailo land.

3. 'Lost Counties' was a reference to the former Kingdom of Bunyoro comprising of two counties of Buyaga and Bugangaizi which were give to Buganda for its collaboration with the British against Bunyoro as war booty.

4. The clan heads led the Bataka movement in Buganda Kingdom. The 1900 Buganda Agreement as it had not specified the precise rights peasants had dissatisfied them. They were also against the payment of dues per annum, 
busulu and a tithe, envijjo, in respect of each acre. This was partly resolved through the passing the Envujjo and Busulu laws in 1928.

5. There are unconfirmed reports that President Museveni is the third Jargest landowner in Uganda next only to government and the Kabaka (king of Buganda). As a commentator put it: 'The president has huge chunks of land in three other parts of the country. Unconfirmed rumours have it that after the Uganda Government, and the King of Buganda, Ronald Mutebi, Museveni is the third largest land owner in Uganda', Onyango-Obbo, 'Will Museveni Go the Rawlings Way?', The East African, Monday, 25 December 25.

\section{References}

Barrows and Roth, 1990, Land Tenure and Investment in African Agriculture: Theory and Evidence, Journal of Modern African Studies, 28:2.

Bazaara, N., 2000, Civil Society and the Struggle for Land Rights for Marginalised Groups: The Contribution of the Uganda Land A lliance to the Land Act, 1998, Paper presented to a workshop on 'Civil Society and Governance', held at the Centre for Basic Research (CBR), Kampala, May 31-June 1.

Bazaara, N., 1992, Land Policy and Evolving Forms of Land Tenure in Masindi District, Uganda, Centre for Basic Research, Working Paper, No.28.

Bazaara, N., Muhereza, F., and Ddungu, E., 1992, A Synopsis of the Dynamics of the Land Question in Uganda, Centre for Basic Research, Kampala, mimeo.

Brenner, Robert, 1982, Agrarian Roots of European Capitalism, Past and Present, No. 97.

Bromley, D.W., and Cornea, M.M., 1989, Management of Common Property Natural Resources: Some Conceptual and Operational Fallacies, Discussion Paper, No.57, The World Bank.

Bruce, J.W., 1986, Land Tenure Issues in Project Design and Strategies for Agricultural Development in Sub-Saharan Africa, Land Tenure Centre, Wisconsin, Land Tenure Centre Paper, No.128.

Ddungu, E., 1991, A Review of the MISR-Wisconsin Land Tenure Study on Land Tenure and Agricultural Development in Uganda, Centre for Basic Research, (CBR), Working Paper, No. 11.

Deininger, K., and Feder, G., 1999, Land Institutions and Land Markets, Internet, mimeo.

Dowall, D.E., 1991, The Land Market Assessment: A New Tool for Urban Management, UNDP/UNHS, (Urban Management Programme).

Hodgson, G. M., 1988, Economics and Institutions: A Manifesto for a Modern Institutional Economics, Oxford, Polity Press.

Izumi, K., 1998a, 'Economic Liberalisation and the Land Question in Tanzania' Unpublished Ph.D Dissertation, International Development Studies, Rosklide University, Denmark.

Izumi, K., 1998b, Process and Structure on the Land Question in Africa: Some Theoretical Issues, Working Paper, No.8. Centre for Development and Environment, University of Oslo. 
Juma, Okuku A., 2000, 'Dynamics of Land Markets in Peri-Urban Kampala, Uganda, A preliminary research paper presented at The Nordic A frica Institute, Uppsala, Sweden, under the Research Programme, "The Political and Social Context of Structural Adjustment in Sub-Saharan Africa', 12 A pril, mimeo. Juma, Ckuku A., 1998, 'Land Tenure and Development in Uganda: A Contribution to the Debate on the Land Bill' 1997, Department of Political Science, Makerere University, Discussion Paper, No. 10, 30 April.

Juma, Okuku A., 1997, 'Institutions and Industrial Policy in Soutlı Korea: What Lessons for Uganda', Makerere Political Science Review, Vol. I No.l.

Juma, Okuku A., 1996, 'Rapporteur Report on "The Draft Tenure and Control of" Land Bill', Makerere Institute of Social Research (MISR), Workshop, Jinja, 4-6, September.

Kiapi, A., 1975 'Legal Obstacles to Rural Development in Colonial Uganda' Mawazo, Vol.4. No.3.

Lipton, M., 1991, 'Towards a Theory of Land Reform', mimeo.

Mafeje, A., 1973, Agrarian Revolution and the Land Question in Buganda', Institute of Social Studies, (ISS), Occasional Papers, The Hague.

Makubuya, K., 1981, 'Land Law Reform and Rural Development in Uganda, in Nsibambi', A., and Katorobo, J., (eds.), Rural Rehabilitation and Development, Proceedings of the Conference on Rural Rehabilitation and Development, held at Makerere University, September 14-18.

Mamdani, M., 1976, Politics and Class Formation in Uganda, New York: Monthly Review Press.

Mijumbi, P. B., 2000, 'The Land Act Implementation of and Issues to Consider in Advocacy for a Land Policy in Uganda', 29 May, mimeo.

MISR-W/isconsin Study, 1989, 'Land Tenure and Agricultural Development in Uganda', Kampala: Makerere Institute for Social Research, (MISR), January. Mukubwa-Tumwine, 1977, 'The Economic and Political Basis of Land Law and Policy in Buganda, 1900-1966', Makerere Law Journal, Vol. I. No.I.

Mukwaya, A. B., 1953, Land Tsmure in Buganda: Present Day Tendencies, Nairobi and Kampala: The Eagle Press.

Nsabasagani, X., 1997, Land Privatisation, Security of Tenure and Agricultural Production: The Uganda Experience, Institute of Social Studies (ISS), Working Paper Series, No.263, November.

Obol-Ochola, 1970, 'Customary Law and Development in Uganda, LMIM Dissertation, University of Dar es Salaam.

Okoth-Ogendo, 1982, 'The Perils of Land Tenure Reform', Paper presented at a Workshop on Land Policy and Agricultural Production in Eastern and Southern African Countries, Gaborone, Botswana.

Platteau, J.P., 1995, Reforming Land Rights in Sub-Saharan Africa: Issues of Efficiency and Equity, UNRISD, Discussion Paper, No.60, Geneva.

Parliament of Uganda, 1997, The Land Bill, 1997, Kampala.

Republic of Uganda, 1998, The Land Act, 1998, Entebbe: Uganda Government Printing and Publishing Corporation. 
Republic of Uganda, 1995, The Constitution of the Republic of Uganda, Entebbe:

Uganda Government Printing and Publishing Corporation.

Republic of Uganda, 1975, The Land Reform Decree, Entebbe: Uganda Government Printing and Publishing Corporation.

Republic of Uganda, 1969, The Public Land Act, Entebbe: Uganda Government Printing and Publishing Corporation.

Republic of Uganda, 1962, The Public Land ACt, Entebbe: Uganda Government Printing and Publishing Corporation.

Skarstein, R., 1990, Agriculture, Not the Leading but the Crucial Sector in Economic Development: Some Reflections on Experience and Theory, Department of Economics, University of Trondheim, Denmark, September, mimeo.

Trout, Elizabeth, 1994, 'Land Markets in Central Province, Uganda', Ph.D. Dissertation, Department of Agricultural Economics, University of Wisconsin, Madison.

West, Henry, T., 1972, Land Policy in Buganda, Cambridge: Cambridge University Press.

White, G., 1993, Towards a Political Analysis of Markets, IDS Bulletin, Vol.24, No.3, July. 